\title{
INTERNATIONAL CALENDAR MARCH 2019
}

\section{9}

\section{ASIL $113^{\text {th }}$ Annual Meeting (American Society of International Law)}

"International Law as an Instrument." The annual meeting will focus on the distinctive ways international law serves as an instrument that national and international actors invoke and deploy, and by which they are constrained. Programs include "Senate v. President: A Moot Court on Treaty Withdrawal Powers" and "Assessing Professional and Judicial Integrity in International Tribunals." Honorees and keynote speakers include Justice Stephen G. Breyer of the U.S. Supreme Court and Zeid Ra'ad Al Hussein, former UN High Commissioner for Human Rights.

March 27-30, 2019

Washington, DC, USA

https://www.asil.org/annualmeeting

\section{Socio-Legal Studies Association Annual Conference}

April 3-5, 2019

University of Leeds, UK

https://www.slsa.ac.uk/index.php/annual-conference?id=322

\section{1st Commonwealth Law Conference (Commonwealth Lawyers Association)}

The Commonwealth Lawyers Association, along with the Law Association of Zambia, will be presenting the $21^{\text {st }}$ Commonwealth Law Conference on the theme "The Rule of Law in Retreat? Challenges for the Modern Commonwealth." The conference will be focusing on various streams on Corporate \& Commercial, Constitutional \& Human Rights, Legal \& the Judicial Profession, and Contemporary Legal Topics.

April 8-12, 2019

Livingstone, Zambia

http://www.commonwealthlawconference.org/

\section{ACRL Conference (Association of College \& Research Libraries)}

"Recasting the Narrative." Librarians must continually reinvent themselves to stay on the cutting edge. Join your colleagues in Recasting the Narrative of what it means to be a librarian in the $21^{\text {st }}$ century, adapting and leading the transition to new roles. Keynote speakers include Michele Norris, Viet Thanh Nguyen, and Alison Bechdel.

April 10-13, 2019

Cleveland, OH, USA

https://conference.acrl.org/

\section{ICOLIS2019 (International Conference on Libraries, Information \& Society)}

"Revitalizing the Library for the Nation." Themes include Library in the Digital Age; Library in the Service of Society; and Library in Teaching, Learning and Profession.

April 18-19, 2019

Melaka, Malaysia

https://umconference.um.edu.my/ICOLIS2019 


\section{ILO Conference on Learning Information Literacy Across the Globe}

The conference will cover literacy in connection to other literacy concepts, digital learning resources for information literacy, and comparative studies of curricula.

May 10, 2019

DIPF German Institute for Educational Research, Frankfurt am Main, Germany

https://informationliteracy.eu/conference/

\section{World Technology Law Conference (ITECHLAW: International Technology Law Association) May 15-17, 2019 \\ Boston, MA, USA \\ https://www.itechlaw.org/Boston2019}

\section{CALL/ ACBD 2019 (Canadian Association of Law Libraries)}

"Get Informed/ Be Inspired/ Innovate"/ Renseignez-vous/ Laissez-vous Inspirer/ Innovez."

May 26-29, 2019

Edmonton, AB, Canada

https://www.callacbd.ca/Conference

\section{ALWD 2019 Biennial Conference (Association of Legal Writing Directors) \\ "A Time for Transformative Leadership: Teaching and Learning." \\ May 29-31, 2019 \\ Suffolk University Law School, Boston, MA, USA \\ http://www.alwd.org/events/biennial-conference/}

\section{Teaching the Teachers Conference}

Sponsored by Georgia State University College of Law, Penn State Law, and the RIPS-SIS and ALL-SIS Special Interest Sections of AALL. This course will provide a foundation in instructional philosophy, techniques, and assessment for law librarians by law librarians. Unlike other similar courses provided by other organizations, this program will be a peer-to-peer, hands-on learning environment where we will be able to leverage our collective similar experiences to enhance the work that we do. Topics include instructional design and planning, presentation and delivery, and assessment and metrics.

May 30-31, 2019

Atlanta, GA, USA

https://elibrary.law.psu.edu/tttconference/

\section{Congress 2019 of the Humanities and Social Sciences}

"Circles of Conversation." Seventy different scholarly associations will be holding their own annual conferences at Congress 2019, making it the largest academic gathering in Canada.

June 1-7, 2019

Vancouver, BC, Canada

https://www.congress2019.ca/

\section{CAPAL-ACBES19 (The Canadian Association of Professional Academic Librarians)}

"The Politics of Conversation: Identity, Community, and Communication." The conference provides an opportunity for the academic library community to critically examine and discuss the ways in which our professional is influenced by its social, political, and economic environments.

June 2-4, 2019

Vancouver, BC, Canada

https://conference.capalibrarians.org/main/ 


\section{ACURIL 2019 (Association of Caribbean University, Research and Institutional Libraries)}

"Access and opportunity for all: Caribbean Libraries, Archives and Museums Supporting the United Nations Sustainable Development Goals." The 2019 ACURIL Conference seeks to upgrade and expand the knowledge base of Caribbean librarians and other information professionals on the Sustainable Development Goals and the progress that has been made since the implementation of these goals in 2015.

\section{June 2-6, 2019}

Oranjestad, Aruba

https://www.smore.com/x9tvk-acuril-2019-aruba-presentations

\section{Institute for Law Teaching and Learning Summer Conference}

"Teaching Today's Law Students." A conference addressing the many ways that law professors and administrators are reaching today's law students. With the ever-changing and heterogeneous nature of law students, this topic has taken on increased urgency for professors thinking about effective teaching strategies. The conference theme is designed to encompass a wide variety of topics, including generational research about current law students, classroom behavior in the current political climate, and techniques for providing effective formative feedback to students.

June 3-5, 2019

Washburn University School of Law, Topeka, KS, USA

https://lawteaching.org/conferences/

\section{CALIcon19 $\left(29^{\text {th }}\right.$ Annual Conference for Law School Computing)}

The CALIcon Conference is one of the longest-running legal education conferences in the United States. The conference brings together law school faculty, librarians, IT professionals, and administrators to share ideas, innovations, experiences, and best practices in legal education/technology that you can use at your law school.

June 6-7, 2019

University of South Carolina School of Law, Columbia, SC, USA

https://www.cali.org/CALI-Conference

\section{The Teaching Professor Conference}

This two-and-a-half-day event presents the newest thinking on improving teaching and learning. Learn from innovators whose presentations showcase the proven methods and approaches that they've used with their students.

June 7-9, 2019

New Orleans, LA, 2019

http://www.TeachingProfessorConference.com

\section{Open Repositories Conference}

This is a practitioner-based conference that brings together people from higher education, government, libraries, archives, and museums to focus on repository infrastructure, tools, services, and policies, providing a forum for delegates from around the world to explore the challenges and opportunities that arise at the interface of technology and scholarly publishing and practice.

June 10-13, 2019

University of Hamburg, Germany

https://10times.com/open-repositories-conference-hamburg

\section{6th ASLI Conference (Asian Law Institute)}

"The Rule of Law and the Role of Law in Asia." Every country in Asia embraces the rule of law in theory, but differences sometimes emerge as to what it means in practice. At the national level, many jurisdictions manifest pluralism through the mix of indigenous, colonial, and national legal projects in the course of their history.

June 11-12, 2019

National University of Singapore Faculty of Law

https://law.nus.edu.sg/asli/16th_asli_conf/index.html 


\section{BIALL 50 ${ }^{\text {th }}$ Annual Conference (British \& Irish Association of Law Librarians)}

"50 Not Out: Past, Present, Future." Presentations will explore innovation, best practices, and empowerment, celebrating achievements and speculating on the future. The keynote speaker will be Baroness Hale, President of the Supreme Court of the United Kingdom.

June 13-15, 2019

Bournemouth, UK

https://biall.org.uk/annual-conference/conference-2019-bournemouth/

\section{SLA 2019 Annual Conference and Info-Expo (Special Libraries Association) \\ June 14-18, 2019 \\ Cleveland, OH, USA \\ https://connect.sla.org/ac2019/home}

\section{EBLIP10: International Evidence Based Library and Information Practice Conference}

"Using evidence in times of uncertainty." In an era of library de-funding, calls for accountability, fake news, and complex information environments, evidence is becoming more important. This inclusive conference theme will encourage evidence-based practitioners and researchers to think about what evidence is, how we collect it, and how we use it in these uncertain times.

June 16-19, 2019

University of Strathclyde, Glasgow, Scotland, UK

https://www.eblip10.org/

\section{MELCom International: Annual Meeting of the European Association of Middle East Librarians}

The annual meeting will be hosted jointly by the Università degli Studi di Napoli L'Orientale and the National Library of Naples Vittorio Emanuele III.

June 18-21, 2019

Naples, Italy

https://www.melcominternational.org/?page_id=1446

\section{European University Institute Conference}

"Corruption, Democracy and Human Rights: Exploring New Avenues in the Fight Against Corruption." The purpose of the conference is to investigate the legal nexus between corruption, democracy deficits, and human rights in the European and global legal orders and to explore new approaches in the fight against corruption that could complement the current legal framework and render it more effective.

June 20-21, 2019

Florence, Italy

http://www2.port.ac.uk/school-of-law/school-events/corruption-democracy-and-human-rights-exploringnew-avenues-in-the-fight-against-corruption/

\section{ALA Annual Conference (American Library Association)}

Programs include "Leaning International: Stories from the Field" and "Will They Stay or Will They Go? Sense of Belonging as a Foundation for Creating Inclusive Library Services for International Students."

June 20-25, 2019

Washington, DC, USA

https://2019.alaannual.org/

\section{IATUL Annual Conference (International Association of University Libraries)}

"Shifting Sands and Rising Tides: Leading Libraries Through Innovation." Technology has fundamentally changed the role of the academic library and how it operates. This is evident in the increased access to digital sources of knowledge, and digital tools and services for students, teachers, and researchers along with the increasingly important role of the library's physical place on campus. The IATUL 2019 conference themes will provide 
ample opportunity to explore and learn about how the library can enable work, study, and research in higher education.

\author{
June 23-27, 2019 \\ Perth, WA, Australia \\ http://www.iatul2019.org/?pgid=1486
}

\title{
LIBER 2019 Annual Conference (Association of European Research Libraries)
}

The LIBER conference brings library directors and their staff together for three days of networking and collaboration. Delegates mainly come from Europe, but people from around the world are welcome. The goal of the conference is to identify the most pressing needs for research libraries, and to share information and ideas for addressing those needs.

June 26-28, 2019

Trinity College, Dublin, Ireland

https://liberconference.eu/

\section{CILIP Conference 2019 (Chartered Institute of Library and Information Professionals)}

July 3-4, 2019

University of Manchester, UK

http://cilipconference.org.uk/

\section{CAFLL (Chinese and American Forum on Legal Information and Law Libraries}

"Evolving Technology and Strengths in Academic Law Libraries."

July 9-11, 2019

American University Washington College of Law, Washington, DC, USA

https://cafllnet.org/

\section{AALL Annual Meeting (American Association of Law Libraries)}

"Capitalizing on our Strengths." Keynote speaker is Shon Hopwood, author of Law Man: Memoir of a Jailhouse Lawyer.

July 13-16, 2019

Washington, DC, USA

https://www.aallnet.org/conference/

\section{IAML Congress 2019 (International Association of Music Libraries and Documentation Centers)}

The IAML Congress Kraków 2019 will offer a program with lectures, discussion panels, and poster sessions on current topics and projects in music librarianship and musicology.

July 14-19, 2019

Jagiellonian University, Kraków, Poland

http://www.iaml2019.confer.uj.edu.pl/en_GB/

\section{3rd Annual Meeting Society of American Archivists}

“Archives * Records 2019: Transformative!" A joint annual meeting of the Council of State Archivists and the Society of American Archivists.

July 29-August 3, 2019

Austin, TX, USA

https://www2.archivists.org/am2019

\section{IDEAL'19: Advancing Inclusion, Diversity, Equity, and Accessibility in Libraries \& Archives}

IDEAL'19 will provide an opportunity for professionals at every level and across sectors to discuss how increasing workplace diversity and creating an inclusive workplace environment improves organizational effectiveness, creativity, adaptability, and relevance to the communities served by the organization. 
August 6-7, 2019

Ohio State University, Columbus, OH, USA

https://library.osu.edu/events/ideal-19-advancing-inclusion-diversity-equity-and-accessibility-in-librariesarchives

\author{
ABA Annual Meeting (American Bar Association) \\ August 8-13, 2019 \\ San Francisco, CA, USA \\ https://www.americanbar.org/events-cle/mtg/annual/214483984/
}

\title{
LIS 2019-Summer (International Conference on Library and Information Science)
}

"Digital transformation and the challenges of the new information environment: reinventing library for the next user generation." LIS 2019-Summer aims to offer a forum for scholars, educators, LIS practitioners, and professionals from different countries to share research achievements and to establish a research network and to find global partners for future collaboration.

August 14-16, 2019

Kyoto, Japan

https://summer.iconlis.org/

\section{IFLA World Library and Information Congress}

With thousands of library and information professionals, from all corners of the world, all types of library, and all career stages coming together, the WLIC provides a unique opportunity to learn and grow, both for individuals, and the library field as a whole. Echoing the Athenian agora of over two thousand years ago, the IFLA World Congress will bring the latest ideas and innovations to bear in the service of better library services and a strong library field.

August 24-29, 2019

Athens, Greece

https://www.ifla.org/annual-conference

\section{AoIR 2019 (Association of Internet Researchers)}

"Trust in the System." The Association of Internet Researchers is a member-based, academic association dedicated to the promotion of critical and scholarly internet research independent from traditional disciplines and existing across academic borders.

October 2-5, 2019

Brisbane, QLD, Australia

http://aoir.org/

\section{DILA $30^{\text {th }}$ Anniversary International Conference (Foundation for the Development of International}

\section{Law in Asia)}

"DILA at 30: The Grand Anatomy of State Practice in International Law in Asia for the Last 30 Years: Past, Present, and Future."

October 15-18, 2019

Universitas Indonesia, Jakarta, Indonesia

http://dila-korea.org/30th2/html/index.html

\section{LIANZA 2019 (Library and Information Association of New Zealand Aotearoa)}

"Our Families, Our Communities, Our Libraries."

October 21-23, 2019

Auckland, NZ

https://lianza.org.nz/conferences/lianza-2019 
38th Annual Course of the International Association of Law Libraries (IALL)

“Law Down Under: Australia's Legal Landscape.” Programs include Australia’s Legal History \& Colonial Legacy, Australia's Constitutional Quirks, a panel on Australian Indigenous Peoples and the Law, and a pre-conference workshop on The Australian Legal System and Legal Research.

October 27-30, 2019

Sydney, NSW, Australia

http://iall.org/conf2019/

2020

AALS Annual Meeting (Association of American Law Schools)

January 2-5, 2020

Washington, DC, USA

https://www.aals.org/events/

ALA Midwinter Meeting (American Library Association)

January 24-28, 2020

Philadelphia, PA, USA

http://www.ala.org/conferencesevents/upcoming-annual-conferences-midwinter-meetings

ABA Midyear Meeting (American Bar Association)

February 12-18, 2020

Austin, TX, USA

https://www.americanbar.org/groups/departments_offices/meetings_travel_dept.html

ASIL Annual Meeting (American Society of International Law)

April 1-4, 2020

Washington, DC, USA

https://www.asil.org/annualmeeting

SCECSAL XXIV (Standing Conference of Eastern, Central and Southern African Library and

Information Associations)

Africa."

"Inclusive libraries and information services toward achieving prosperity for sustainable development in

April 20-24, 2020

Windhoek, Namibia

http://scecsal2020.org/

SLA Annual Conference (Special Libraries Association)

June 6-9, 2020

Charlotte, NC, USA

https://connect.sla.org/ac2020/home

\section{ALA Annual Conference (American Library Association)}

June 25-30, 2020

Chicago, IL, USA

http://www.ala.org/conferencesevents/upcoming-annual-conferences-midwinter-meetings 
AALL Annual Meeting (American Association of Law Libraries)

July 11-14, 2020

New Orleans, LA, USA

https://www.aallnet.org/conference/about/future-meetings/

IFLA World Library and Information Congress (International Federation of Library Associations and Institutions)

July 28-August 5, 2020

Auckland, NZ

https://www.ifla.org/annual-conference

\author{
ABA Annual Meeting (American Bar Association) \\ July 30-August 4, 2020 \\ Chicago, IL, USA \\ https://www.americanbar.org/groups/departments_offices/meetings_travel_dept.html \\ 39th Annual Course of the International Association of Law Libraries (IALL) \\ October 4-7, 2020 \\ Toulouse, France \\ http://iall.org/annual-conference-2/
}

2021

AALS Annual Meeting (Association of American Law Schools)

January 5-9, 2021

San Francisco, CA, USA

https://www.aals.org/events/

\title{
ALA Midwinter Meeting (American Library Association)
}

January 22-26, 2021

Indianapolis, IN, USA

http://www.ala.org/conferencesevents/upcoming-annual-conferences-midwinter-meetings

ABA Midyear Meeting (American Bar Association)

February 10-16, 2021

Orlando, FL, USA

https://www.americanbar.org/groups/departments_offices/meetings_travel_dept.html

ASIL Annual Meeting (American Society of International Law)

March 24-27, 2021

Washington, DC, USA

https://www.asil.org/annualmeeting

\section{ALA Annual Conference (American Library Association)}

June 24-29, 2021

Chicago, IL, USA

http://www.ala.org/conferencesevents/upcoming-annual-conferences-midwinter-meetings 
AALL Annual Meeting (American Association of Law Libraries)

July 17-20, 2021

Cleveland, OH, USA

https://www.aallnet.org/conference/about/future-meetings/

\section{ABA Annual Meeting (American Bar Association)}

August 5-10, 2021

Toronto, ON, Canada

https://www.americanbar.org/groups/departments_offices/meetings_travel_dept/future-past-meetings/

2022

ALA Midwinter Meeting (American Library Association)

January 22-25, 2022

San Antonio, TX, USA

http://www.ala.org/conferencesevents/upcoming-annual-conferences-midwinter-meetings

\section{ALA Annual Conference (American Library Association)}

June 23-28, 2022

Washington, DC, USA

http://www.ala.org/conferencesevents/upcoming-annual-conferences-midwinter-meetings

\section{AALL Annual Meeting (American Association of Law Libraries)}

July 16-19, 2022

Denver, CO, USA

https://www.aallnet.org/conference/about/future-meetings/

ABA Annual Meeting (American Bar Association)

August 4-9, 2022

Chicago, IL, USA

https://www.americanbar.org/groups/departments_offices/meetings_travel_dept/future-past-meetings/ 